\title{
Analysis on ASEAN and European Union Policies Regarding Covid-19
}

\author{
Shanti Darmastuti ${ }^{1}$, Mansur Juned ${ }^{2}$, Sophiana Widiastutie ${ }^{3}$ \\ ${ }^{1,2,3}$ Faculty of Social and Political Science, Universitas Pembangunan Nasional Veteran Jakarta, Indonesia \\ shanti.darmastuti@upnvj.ac.id,mansurjuned@upnvj.ac.id,sophianaw@yahoo.com
}

\begin{abstract}
COVID-19 has impacted multiple sectors of life. Experts believe that regional cooperation is a key effort that should be done to deal the COVID-19 pandemic. Regional cooperation starts with common interests among parties and provides benefits for every country involved in it. This article provides an overview of the socio-economic impact of COVID-19 as well as a comparison of the forms of regional cooperation carried out by Association of Southeast Asian Nations (ASEAN) and the European Union (EU) in responding COVID-19. This study uses literature studies in data collection. From the results of several studies that have been carried out before, both regions chose to conduct cooperation in the health and economic fields to respond to COVID-19. ASEAN's response in responding to the pandemic can be seen stronger in the principles of partnership that have been established with several partner countries. In addition, the principle of solidarity, exchange of information, knowledge, as well as strengthening institutional cooperation in ASEAN itself is an important point in the regional cooperation carried out. On the other hand, in addition to cooperation in the health sector, EU focuses on financial instruments among its collaborative approaches in the availability of aid packages to banking actors and institutions. The package of assistance provided by the EU to avoid market distortions and revive economic sectors is provided through the provision of credit and liquidity.
\end{abstract}

\section{Keywords}

COVID-19; cooperation, regional; ASEAN;

European Union

\section{Introduction}

COVID-19 is a global health problem including Indonesia. This was initiated from the information of the World Health Organization (WHO) on 31 December 2019 there was a case of a cluster of pneumonia with a new etiology in Wuhan City, Hubei Province, China and later expanded beyond China. On 30 January 2020, COVID-19 was set to become the public health Emergency of International Concern (PHEIC). On 11 March 2020, COVID-19 was designated as a pandemic. (Susilawati et al, 2020)

The COVID-19 pandemic does not discriminate any sector. Trade restrictions imposed by many countries have significantly slowed the tourism sector. Not so far from tourism, the trade and other business sectors are also shattered by the pandemic. Unemployment soars coined by the reality that most corporations restrict and even halt their operational activities from not having sufficient fund. The migrant workers are also getting the downside of the pandemic from the repatriation regulations imposed by many countries. Moreover, informal workers have also lost their source of income from social distancing and lockdown restrictions. 
Transportation and labor mobility restrictions have given significant impact to the economy production capacity. This is because there is a change of demand due to people's declining income. Hence, in order to stop the COVID-19 spreading, the pandemic affects people's mobility and cross-border goods transport. Governments across the globe have chosen to apply stimulus regulations for health and macro economy sectors. For instance, in the health sector, government adds budget to purchase masks, protective gears, and research to formulate vaccines. On the other hand, in macro economy sector, governments have chosen to give financial aid in cash and supplies for the less advantaged and tax relief for business actors.

The government's response to the pandemic is vital for every country to protect their citizens. Not only in the national level, cooperation in international level is also needed to monitor and respond viral infections. For example, we can see how the international health organization(s) conduct cooperation to respond global viral disease. The commitment within international commitment is a form of obligation from each country to collectively fight against economy struggle. Cooperation is needed to protect the citizens and to anticipate other impacts from the pandemic on social and political sectors. The race for vaccine is also a vital agenda in the international cooperation (Rubenstein, 2010).

Rubenstein (2010) sees that technology advances supported by financial aid from the developed countries has become one of the stimuli towards international cooperation against viral diseases. Regional cooperation motivated by mutual interests to tackle the pandemic will benefit all the countries involved in the cooperation. Technical cooperation is also one of the efforts done in regional cooperation in response against viral diseases. Regional approach mixed with well-defined procedure from international health organization is important to build a nation's capacity to tackle a disease. Government transparency and democratic and inclusive cooperation will bring regional cooperation into success. Through this type of cooperation, all countries involved within will gain benefits from their contribution to fight the viral disease.

Therefore, regional cooperation is one of the efforts that can possibly be done to fight COVID-19 pandemic. Through regional cooperation, both technical and financial, countries are expected to be able to tackle the downsides of the pandemic in health, trade, human resource, and many other sectors. Countries are also expected to anticipate prolonging impacts in social and economy better.

\section{Review of Literature}

We can see a regional cooperation effort example in the East Asia. This pandemic forces East Asian countries to collaborate in a regional cooperation to tackle the pandemic with its tailing economy issues. The starting approach that could be done in this cooperation is a coordinated approach to people's mobility in each country that can calm the economic shock from the pandemic. Coordination and regional cooperation aim to increase resource allocation to vital sectors and hospitals to keep the welfare of health workers. The cooperation also provides regional platform to manage and maintain Global Value Chain activity after pandemic (Kimura, et.al, 2020: 16-17).

COVID-19 pandemic also strikes greatly in the Latin America region. The pandemic has successfully stirred up the Latin America countries due to their ineffective, unfair, fragmented, and weak health systems; hence, they decide to gather strengths to tackle the problem together. The crucial cooperation in the Latin America is done through science diplomacy. Scientists, diplomats, governments, academics, and citizens of Latin America work together to find the best medical solution against COVID-19. One of the few fruits of 
this cooperation is vaccine making and trials due to the high numbers of COVID-19 patients (Echeverria, Valle, \& Muller, 2020: 170-179).

In relation to this regional cooperation, Amaya \& Lombaerde (2021:3-4) sees that cooperation through organizations at the regional level is also needed in responding to COVID-19. For example, the Pan American Health Organization (PAHO) in dealing with the COVID-19 pandemic is collaborating with its member countries to share knowledge about the development of COVID-19 and the formulation of vaccines through the COVID19 Technology Access Pool (C-TAP) program initiative. This program provides easy access for PAHO member countries to obtain vaccines, medicines, and other health products. This kind of collaboration has also been carried out by PAHO with Mercosur in 2015 in dealing with HIV/AIDS cases so that they can obtain medicines that save 20 million US dollars.

In ASEAN, the members agreed to establish the ASEAN COVID-19 Response Fund to fund medical equipment and emergency assistance for all countries in Southeast Asia. The source of these funds comes from available reallocation and support from partners, especially ASEAN Plus One and ASEAN Plus Three, namely Japan, South Korea, and China. It can be said that the ASEAN COVID-19 Response Fund is a forum that facilitates ASEAN Regional cooperation in dealing with COVID-19. Thus, ASEAN member countries can be assisted in dealing with this pandemic domestically (Widian \& Omega W, 2020: 33-35).

Other study conducted by Murphy, et al. (2020: 5-7) focuses on the response to regional cooperation carried out by the Caribbean Community (CARICOM). CARICOM is a regional organization in the Caribbean Islands, which aims to promote the economic integration and cooperation of its member countries. During the COVID-19 pandemic, CARICOM members have agreed to collaborate with main focus on the health sector. Members of CARICOM also agreed to issue policies for implementing non-pharmaceutical interventions for all its member countries. Non-pharmaceutical intervention is a way to reduce the spread of the virus through reducing contact and interaction between individuals, so that the spread of COVID-19 can be controlled easier.

The regional organization EU, which is also affected by the COVID-19 pandemic, is making efforts to accelerate the country's recovery process member countries, both in terms of financial and health. In this case, the EU as a regional organization makes efforts to accelerate the recovery process through financing obtained from EU revenue streams used to fund the recovery of its member countries. This financing instrument is in the form of a recovery package called the Next Generation EU (NGEU) Recovery Plan worth 750 billion Euros, as well as the Multiannual Financial Framework (MFF) budget for the period 2021-2027. NGEU and MFF 2021-2027 have provided increased investment especially in terms of preparing EU public health for the future. It also includes EU programs that aim to provide emergency health assistance and EU public health research. With the NGEU and MFF 2021-2027, member countries also get financial relief while also being able to prepare a reserve budget to deal with future crisis (Fernandez, 2020: 1420-1421).

From the results of the several studies that have been carried out above, it can be seen that member countries use regional cooperation both in the health and financial fields out to respond to COVID-19. The cooperations mostly aim to prevent the spread of the pandemic and to address economic problems that rises due to the pandemic. Based on the existing literature review, this article will provide an overview of the socio-economic impact of COVID-19 in ASEAN and EU as well as their policy comparison. 


\section{Research Methods}

This comparative analysis study of ASEAN and EU policies in dealing with COVID19 uses literature study in data collection techniques. The collected data come from reports issued by ASEAN, the EU, and other international institutions such as the ADB as well as articles from journals and the internet that discuss ASEAN and EU's responses against COVID-19. In looking at regional cooperation, the author analyzes several collaborative steps that have been carried out at the regional level both in ASEAN and in the EU.

\section{Results and Discussion}

\subsection{Social Economic Impact from Covid-19}

Generally, the COVID-19 pandemic gives economic impact in terms of trade costs, productivity, and changes in policy. The Asian Development Bank (ADB) (2020: 3) looks at the economic impact from several aspects including: 1) Increase in trade costs which will ultimately have an impact on other industries and global supply chains; 2) Productivity decline because of decreasing supply which follows by the decline of corporations' revenues and cuts in workers' wages; 3) The government's policy response in the form of fiscal stimulus in various macroeconomic policy instruments. These three aspects can be seen from the image below:
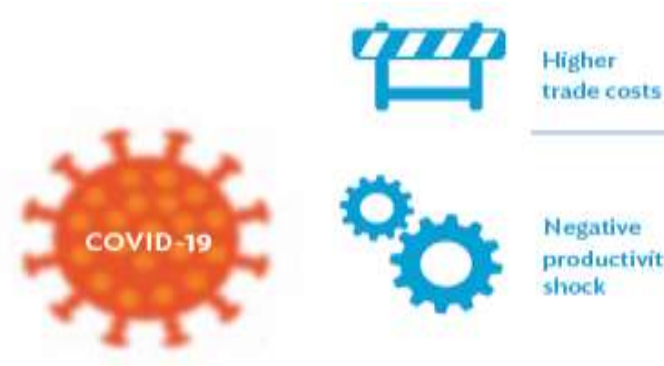

Trade impact:

- Lower tourism arrivals, receipts - Lawer poods trade
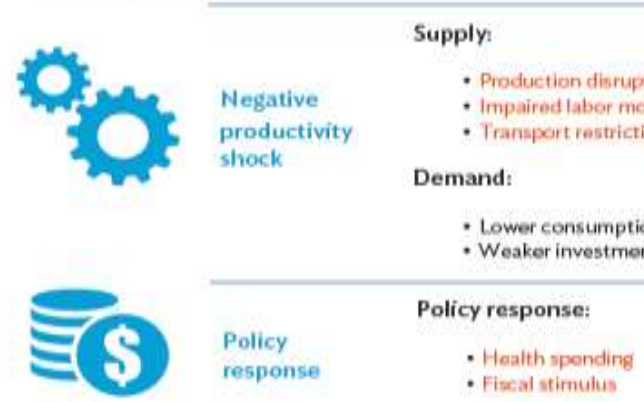

Figure 1. Economic Impact from COVID-19

Source: ADB, 2020

The pandemic has impacted ASEAN's economic sectors such as tourism, trade, and the aviation sector. This happened as a result of the implementation of quarantine in several countries, the closure of business activities, as well as the recommendation for the public to stay at home. On the social side, the cessation of production and business activities has resulted in many workers losing their jobs. In extent, this pandemic has resulted in changes in the economic growth targets that have been set by ASEAN countries in 2020. This target change can be seen in the following table (asean.org, 2020a). 
Table 1. Prediction of Gross Domestic Product (GDP) Growth for ASEAN Member

Countries in 2020

\begin{tabular}{|c|c|c|c|c|c|}
\hline Country & \multicolumn{2}{|c|}{ Initial Forecast } & \multicolumn{2}{|c|}{ Revised Forecast } & \multirow[t]{2}{*}{ Source } \\
\hline $\begin{array}{l}\text { Brunei } \\
\text { Darussalam }\end{array}$ & $1.5 \%$ & Sep 2019 & $2.0 \%$ & 3 Apr 2020 & \\
\hline Cambodia & $6.8 \%$ & Sep 2019 & $2.3 \%$ & $3 \mathrm{Apr} 2020$ & ADB \\
\hline Indonesia & $5.3 \%$ & Official target, & $4.7 \%$ to $5.0 \%$ & 4 Mar 2020 & Ministry of Finance \\
\hline & & Aug 2019 & $-0.4 \%$ to $2.3 \%$ & $1 \mathrm{Apr} 2020$ & \\
\hline Lao PDR & $6.2 \%$ & Sep 2019 & $3.5 \%$ & $3 \mathrm{Apr} 2020$ & ADB \\
\hline Malaysia & $4.8 \%$ & Official target & $\begin{array}{r}3.2 \% \text { to } 4.2 \% \\
-2.0 \% \text { to } 0.5 \%\end{array}$ & $\begin{array}{l}\text { Feb } 2020 \\
3 \text { Apr } 2020\end{array}$ & $\begin{array}{l}\text { Ministry of Finance } \\
\text { Bank Negara Malaysia }\end{array}$ \\
\hline Myanmar & $6.8 \%$ & Sep 2019 & $4.2 \%$ & $3 \mathrm{Apr} 2020$ & $\mathrm{ADB}$ \\
\hline Philippines & $\begin{array}{r}6.5 \% \text { to } \\
7.5 \%\end{array}$ & Official target & $\begin{array}{r}5.5 \% \text { to } 6.5 \% \\
\text { (if outbreak lasts until June) } \\
-0.6 \% \text { to } 4.3 \%\end{array}$ & $\begin{array}{l}\text { Mar } 2020 \\
19 \operatorname{Mar} 2020\end{array}$ & NEDA \\
\hline Singapore & $\begin{array}{r}0.5 \% \text { to } \\
2.5 \%\end{array}$ & Nov 2019 & $\begin{array}{r}-0.5 \% \text { to } 1.5 \% \\
-4 \% \text { to }-1 \%\end{array}$ & $\begin{array}{l}17 \mathrm{Feb} 2020 \\
26 \mathrm{Mar} 2020\end{array}$ & $\begin{array}{l}\text { Ministry of Trade and } \\
\text { Industry }\end{array}$ \\
\hline Thailand & $\begin{array}{r}2.7 \% \text { to } \\
3.7 \% \\
\end{array}$ & Nov 2019 & $1.5 \%$ to $2.5 \%$ & 17 Feb 2020 & $\begin{array}{l}\text { National Economic and } \\
\text { Social Development Board }\end{array}$ \\
\hline Viet Nam & $6.8 \%$ & & $\begin{array}{r}6.27 \% \text { if contained in Q1: } \\
6.09 \% \text { if contained in Q2 } \\
5.98 \%\end{array}$ & $\begin{array}{l}5 \text { Feb } 2020 \\
13 \text { Feb } 2020\end{array}$ & $\begin{array}{l}\text { Ministry of Planning and } \\
\text { Investment }\end{array}$ \\
\hline
\end{tabular}

Source: ASEAN Policy Brief, April 2020

As we can see that almost all ASEAN member countries have made changes to their GDP growth predictions due to the COVID-19 pandemic. For example, the target for Indonesia was set at 5.3\% before this pandemic; the number was later changed in April 2020 by $-0.4 \%$ to $2.3 \%$. Malaysia also made changes to their GDP growth target from $4.8 \%$ to $-2.0 \%$ to $0.5 \%$. The rest of ASEAN member countries have also made changes to their GDP growth targets.

Not only on GDP growth, the impact on the pace of foreign investment in ASEAN is also affected by this pandemic considering that the source of foreign investment in ASEAN comes from the United States (US) and the European Union (EU). The US is the country that has the largest equity portfolio ownership in ASEAN (38.4\%), followed by the EU (27.1\%). In terms of portfolio debt investment in ASEAN, the US and EU are also the largest investors with $22.2 \%$ (US) and $30.6 \%$ (EU). The EU and the US were also major FDI investors at $18.7 \%$, and $14.1 \%$, respectively. With the pandemic also occurring in the US and the EU, this condition will of course have a major impact on investment conditions in ASEAN (ASEAN Policy Brief, 2020:5).

The opening of the ASEAN market for trade and investment has made this region an easy target for the COVID-19 pandemic. The pandemic has stirred the export performance of ASEAN member countries. ASEAN trade and investment partners such as the US, EU, China, and Japan are also struggling to make economic efforts to deal with this pandemic. Therefore, this condition has an impact on ASEAN.

The supply chain at the regional level is heavily affected by this pandemic. ASEAN countries such as Singapore, Malaysia, and Thailand are the most affected countries because they are the only ASEAN member countries with the highest rate of integration with regional supply chains. The decline in demand for goods produced in the country has negatively affected regional supply chains that have been running so far (Menon, 2020).

The COVID-19 pandemic has also dealt a heavy blow to the EU economy with highly severe socio-economic consequences. Although rapid and comprehensive policies have been carried out both at the EU level and at the national level of each member country, the EU economy remains in recession. EU's economy shock hit all member countries, although with different rates for output decline in 2020 (from $-41 / 4 \%$ in Poland to $-93 / 4 \%$ in Greece) and rebound strength in 2021. Economic recovery in each member country depends on the severity growth of the pandemic in theeir country, on their economic structure, and their ability to cope with economic stabilization policies. Given 
the economic interdependence in the EU, the dynamics of recovery in each member country also affects the recovery power of other member countries (European Commission, 2020). Thus, the scenario clearly shows that economic capacity of member countries and the accuracy of policies in responding to the pandemic are keys to resolving the current crisis. Economic stabilization in the region must be put in priority considering the relations between member countries that influence each other.

Currently the EU is in the second wave of COVID-19, where the number of cases continues to increase. Certainly, this has an impact on economic growth in the EU, based on data that EU economic growth in the 3rd quarter of 2020 increased by $11.6 \%$ from the previous quarter (Eurostat, 2020).

Table 2. GDP Growth Rate of EU

\begin{tabular}{|l|c|c|c|c|c|c|c|c|}
\hline & \multicolumn{4}{|c|}{$\begin{array}{c}\text { Percentage change compared with the } \\
\text { previous quarter }\end{array}$} & \multicolumn{3}{c|}{$\begin{array}{c}\text { Percentage change compared with the } \\
\text { same quarter of the previous year }\end{array}$} \\
\cline { 2 - 11 } & $\mathbf{2 0 1 9 Q 4}$ & $\mathbf{2 0 2 0 Q 1}$ & $\mathbf{2 0 2 0 Q 2}$ & $\mathbf{2 0 2 0 Q 3}$ & $\mathbf{2 0 1 9 Q 4}$ & $\mathbf{2 0 2 0 Q 1}$ & $\mathbf{2 0 2 0 Q 2}$ & $\mathbf{2 0 2 0 Q 3}$ \\
\hline Euro area & 0.0 & -3.7 & -11.8 & 12.6 & 1.0 & -3.3 & -14.8 & -4.4 \\
\hline EU & 0.1 & -3.3 & -11.4 & 11.6 & 1.2 & -2.7 & -13.9 & -4.3 \\
\hline
\end{tabular}

Source: Eurostat, News Release Euro Indicators, 2020

From the table above, we can see that there are significant changes starting from the 4th quarter of 2019 when there were no COVID-19 cases in the area until the 1st quarter of 2020, the beginning of COVID-19 pandemic. In the second quarter of 2020, the EU's economic growth continued to experience minus. Over time, in the third quarter of 2020, it turned out that the EU's economic growth had increased quite well. This fact goes hand in hand with the EU's efforts to restore economic growth.

We can also see that COVID-19 has significantly impacted economic performance in ASEAN and EU countries. The economic contraction that occurred was caused by the decline in trade performance, investment, lockdown policies up to the closing of tourism places.

\subsection{ASEAN and European Union Policies in Responding Covid-19}

At the regional level, ASEAN has taken several steps in responding COVID-19 pandemic. For example, all economic ministers of ASEAN member countries affirmed their commitment to maintaining ASEAN economic policies and integration on March 10, 2020. Through this commitment, members have decided that collective action was needed to combat this virus. This collective action takes the form of maintaining the openness of the ASEAN market, strengthening the exchange of information, coordination, and cooperation with industry stakeholders. In addition to these commitments, coordination will also be carried out continuously, especially regarding economic sectors affected by this pandemic. This coordination is aimed at maintaining macroeconomic and financial stability as well as the availability of food and medical supplies. ASEAN cooperation with partnering countries is also one of the policies taken by ASEAN. An example is cooperation in ASEAN+3 by strengthening the Chiang Mai Initiative Multilateralization (CMIM) with provision of short-term liquidity for member countries as one of the policies taken by the group (ASEAN Policy Brief, 2020:12).

Through the 25th Meeting of the ASEAN Coordinating Council (ACC) on April 9, 2020, the foreign ministers of ASEAN member countries have agreed on several policies, including: 1) The need for follow-up in the form of implementation of the results of the 
ASEAN Health Ministers meeting and ASEAN+3; 2) Collective commitment to ensure the flow of food and medicine as well as medical equipment; 3 ) The need for protection of vulnerable ASEAN citizens including migrant workers; and 4) The need for the establishment of the ASEAN COVID-19 Response Fund (Indonesian Embassy in Port Moresby, 2020)

The collaborative commitment among ASEAN member countries was bound deeper through the Declaration of the Special ASEAN Summit on Coronavirus Disease 2019 (COVID-19) on April 14, 2020. This declaration emphasizes on strengthening the ASEAN community in which member countries cooperated with each other to respond the pandemic. Increased cooperation in the public health sector, for example, is carried out through the exchange of information on policies and experiences in dealing with this pandemic. Cooperation in vaccine research and development is also a target in this collaboration. On the social angle, the declaration focuses on aiding affected people by encouraging the operationalization of the ASEAN Guidelines on the Provision of Emergency Assistance. Increasing effective and transparent public communication involving various forms of media is also important to inform updates about COVID-19 and clarify misinformation. Maintaining economic stability is a shared commitment in ASEAN to address the socio-economic impact of COVID-19. This declaration also emphasizes the importance of a comprehensive approach that involves multi-stakeholder and multisectoral response to this pandemic. On the other hand, cooperation is also intended for supply chain connectivity between ASEAN countries. Cooperation with ASEAN partners is important both in the form of financial and technical support (asean.org, 2020b).

The joint statement at the ASEAN+3 meeting in addressing COVID-19 on April 14, 2020 emphasized the need for ASEAN+3 health cooperation in responding to COVID-19. Strengthening cooperation in the exchange of information between member countries in handling this pandemic is one of the goals in the joint statement. Cooperation in technical support in the prevention and handling of these cases is also part of the shared commitment. Research collaborations are also carried out in the context of making antiviral vaccines which involve collaboration with the private sector. The coordination of this research collaboration is carried out through the ASEAN+3 Field Epidemiology Training Network (FETN). This joint statement also confirms a joint commitment to cooperation in post-pandemic economic recovery (kemlu.go.id., 2020).

In addition to ASEAN+3 cooperation, ASEAN+1 cooperation also rose to attention by emphasizing cooperation with each member countries. On February 20, 2020, the China-ASEAN Foreign Ministers Meeting was held to discuss ways to combat COVID-19. In this meeting, the two sides exchanged views on strengthening the synergy between health agencies, as well as the existence of border control cooperation between China and ASEAN. The meeting also discussed China's proposal to establish a China-ASEAN liaison mechanism (Zhengyue \& Xinyu, 2020).

The EU has also responded to regional cooperation with several policies. Based on data from the EU Parliament (europarl.europa.eu, 2020), the policies taken by the European Union in restoring the social and economic situation of countries in the European Region can be seen through these steps below: 
Table 3. EU's Steps to Restore Social and Economy Sector from COVID-19

\begin{tabular}{|c|c|c|}
\hline No & EU Policy & Description \\
\hline 1 & $\begin{array}{l}\text { Provide massive economy } \\
\text { stimulus }\end{array}$ & $\begin{array}{l}\text { The European Commission proposed a } \\
750,000,000,000 \text { EUR stimulus plan. The leaders } \\
\text { of the EU consider the budget and the recovery } \\
\text { plan that is carried out by looking at any risks } \\
\text { that occur from the stimulus that will be given. }\end{array}$ \\
\hline 2 & $\begin{array}{l}\text { Support EU's health system } \\
\text { and infrastructure }\end{array}$ & $\begin{array}{l}\text { EU4Health is a program made to strengthen the } \\
\text { health care systems of EU member states. }\end{array}$ \\
\hline 3 & $\begin{array}{l}\text { Protect small and medium } \\
\text { scale business }\end{array}$ & $\begin{array}{l}\text { The EU opened 1.000.000.000 EUR from the } \\
\text { European Fund for strategic investment awarded } \\
\text { for the banks and lenders to provide liquidity for } \\
\text { more than } 100,000 \text { small scale business in } \\
\text { Europe. }\end{array}$ \\
\hline 4 & $\begin{array}{l}\text { Decrease unemployment } \\
\text { risks }\end{array}$ & $\begin{array}{l}\text { The EU provides financial assistance of up to } \\
100 \text { billion euros to member states. }\end{array}$ \\
\hline 5 & $\begin{array}{l}\text { Encourage tourism and } \\
\text { culture }\end{array}$ & $\begin{array}{l}\text { The EU supports the tourism and culture sector } \\
\text { and introduces various measures that can revive } \\
\text { tourism and culture in the European Region. }\end{array}$ \\
\hline 6 & $\begin{array}{l}\text { Banking packages to support } \\
\text { home business and } \\
\text { households }\end{array}$ & $\begin{array}{l}\text { The EU Parliament approved temporary easing } \\
\text { for banks in the Euro Area. This policy is made } \\
\text { to award loans for employees as well as retires, } \\
\text { to affirm credit flows for small and medium scale } \\
\text { businesses, and to support infrastructure } \\
\text { investment. }\end{array}$ \\
\hline 7 & $\begin{array}{l}\text { Support agriculture and } \\
\text { fishery sectors }\end{array}$ & $\begin{array}{l}\text { The EU Parliament agreed to support the } \\
\text { livelihood of fishers and aquafarmers whose } \\
\text { businesses are stopped during the crisis. The EU } \\
\text { also helps small companies related to the } \\
\text { agricultural sector. }\end{array}$ \\
\hline 8 & $\begin{array}{l}\text { Support member countries in } \\
\text { responding crises }\end{array}$ & $\begin{array}{l}\text { The EU launched a new initiative, channeling } \\
37,000,000,000 \text { EUR from the EU structural } \\
\text { fund. This policy is meant to provide financial } \\
\text { support for EU member states in the current } \\
\text { criitical situation. }\end{array}$ \\
\hline 9 & $\begin{array}{l}\text { Aid policy that supports } \\
\text { member countries of Euro } \\
\text { Zone }\end{array}$ & $\begin{array}{l}\text { The EU decided to launch interim framework } \\
\text { regarding state aid rules. This policy is meant to } \\
\text { help sustaining economic activity during and } \\
\text { after the COVID-19 outbreak by ensuring all } \\
\text { businesses earn sufficient liquidity. Member } \\
\text { countries can provide up to } 800,000 \text { EUR for } \\
\text { industries to fulfil their urgent liquidity needs or } \\
\text { provide loans at favorable interest rates. }\end{array}$ \\
\hline 10 & $\begin{array}{l}\text { Protect the weakened } \\
\text { business actors in Europe } \\
\text { from foreign competitors }\end{array}$ & $\begin{array}{l}\text { The European Parliament calls for equal playing } \\
\text { field for all business actors in order to avoid } \\
\text { distortions within the single market triggered by } \\
\text { unhealthy competitions from foreign companies. }\end{array}$ \\
\hline
\end{tabular}

Source: europarl.europa.eu, 2020 
EU's response to COVID-19 generally focuses on four priorities: limiting the spread of the virus, ensuring the provision of medical equipment, encouraging research for treatments and vaccines, and providing support to jobs, business, and the economy (European Council, 2020).

In addition, the EU tries to combat COVID-19 through a fiscal stimulus policy agreed by EU finance ministers on April 9, 2020. In this case, the finance ministers agreed to provide a fiscal stimulus package of half a trillion euros. The EU Central Bank also issued a program called the Pandemic Emergency Purchase Program. Through this program, the Central Bank purchased additional bonds amounting to USD 810 billion to protect public debt and provide liquidity for members (weforum.org., 2020).

Temporary asset purchases of private and public sector securities are carried out to address the risks of the monetary policy transmission mechanism and the outlook for the euro area. Financial support provided by the Central Bank is expected to help countries in the euro area in responding to the impact of this pandemic. Expectations also expand to economic sectors at the family, company, bank, and government level can benefit from the financing provided (ecb.europa.eu., 2020).

The EU also shows their support for partner countries in responding to COVID-19 through the creation of the "Team Europe" package. The team consists not only of member states but also of EU financial institutions such as the European Investment Bank and the European Bank for Reconstruction and Development. The aid package that will be provided reaches more than 20 billion euros, and this assistance will be given to vulnerable countries in Africa, countries in the EU environment such as the Western Balkans, Middle East and North African countries, parts of Asia and the Pacific, Latin America, and the Caribbean. The assistance provided will be focused on humanitarian assistance because of the health crisis, strengthening the health system, increasing the capacity of partner countries in responding to this pandemic and providing support to the private sector such as small and medium enterprises. As a contributor in the international aid system, the EU coordinates and makes partnerships with the United Nations, international financial institutions, and other multilateral cooperation such as the G7 and G20 in response to COVID-19 (European Union, 2020).

\subsection{Analysis of Regional Cooperation to Face Covid-19}

From several efforts made at the regional level we can see that ASEAN and others Asia countries are giving information to each other, maintain trade, provide mutual assistance regarding medical supplies, as well as other measures to combat the virus. Some cooperation mechanism which made by ASEAN throughout ASEAN+3 or ASEAN+1. This cooperation and coordination are made to solve health issues, potential for an economic recession or any solutions to improve cooperation among other countries. Through strengthening the international cooperation, it is hoped that the Asian region can take a more constructive role in global governance. This can be achieved if the existing regional cooperation mechanism further is integrated in overcoming problems including imbalances in international trade and the global economy, social welfare inequality at the regional level and so on. Therefore, there is a need for strong support from various sectors, not only for trade but also in health, tourism, energy, environment, and other sustainable development. Through comprehensive functional cooperation then those problems can be solved (Zhengyue \& Xinyu, 2020).

Regional cooperation in addressing the problem of the transmission of a virus can also be seen as collaboration together in all forms. In this case, reegional cooperation has also been carried out in addressing Avian Influenza (AI) in 2003. As the response from the 
regional cooperation which is already done, in 2003 Southeast Asia countries responded both through measures taken at the national level and through collective responses at the regional level. Not only through cooperation at the ASEAN level, as in the regional response in responding to COVID-19, when responding to the AI virus, ASEAN also collaborates with partners in the form of ASEAN+3 and discusses it at the East Asia Summit. Several forms of cooperation were carried out at that time, such as forming a team in ASEAN to fight the AI virus through the establishment of the Highly Pathogenic AI (HPAI) Task Force as well as a commitment to coordinate and share information among other member countries. In addition, in response to this virus, ASEAN also made a declaration on the prevention and control of the AI virus (Knapp, 2011:543).

The emergence of HPAI H5N1 virus in the ASEAN region, trigger a response from ASEAN member countries and countries outside the ASEAN region to hold several meetings by political leaders, parliaments, ministers of health, and medical experts from ASEAN member countries, ASEAN+1, and ASEAN+3. The first meeting from ASEAN+1 which conducted in Beijing had made an agreement to make Emerging Infectious Disease (EID) program and enhance cooperation in the ASEAN and China regional public health. Develop procedures for standard operating health for all ASEAN member countries and China is also become an agreement reached at the meeting (Thomas, 2006, pp. 928-929).

The response to this AI virus was also responded by the EU at that time. In this case the EU uses a comprehensive approach in the fight against this virus. Regionally EU create regional protection policies through restrictions on trade in poultry originating from Southeast Asia in 2005. Meanwhile, as it was also done in response to COVID-19, when responding to the AI virus, The EU also provides financial assistance to partner countries for research activities. In fact, in that time WHO recommends the EU's model for policy, contingency planning and surveillance policies for the Asia Pacific region. Interregional cooperation through dialogue in Asia Europe Meeting (ASEM) become the main dialogue forum for ASEAN and the EU for the fight against AI virus. At the meeting of the ASEM Minister of Foreign Affairs in 17-18 April 2004, emerging initiatives regarding public management for emergencies. Also, EU provides technical and financial assistance for ASEAN member countries most severely affected by the AI virus (Knapp, 2011:546-548). The virus threat has created cooperation between regional and interregional region.

From several methods, Information transparency is one of the policies taken at the regional level in responding to the pandemic. For example, transparency of information which made by ASEAN, become very important in regional cooperation. Through this cooperation is expected to have some sort of effort to help overcome the issue of differences in the infrastructure readiness of each member state in response to this pandemic. Policy response and resource enhancement in overcoming the problem of COVID-19 is one of the cooperation that is done to address the differences in the infrastructure. This is important because the issue of medical facilities is very important to note each country. Because of that, through regional cooperation will enable ASEAN countries can identify the problem of the readiness of the infrastructure and the policy response of each member country.

ASEAN response in responding to the pandemic, it can be seen that the emphasis is on the principle of partnership that has been established with several partner countries, both within the framework of ASEAN+1, ASEAN+3 and cooperation with the EU. Also, the principle of solidarity are important values to improve internal cooperation in ASEAN. The exchange of information, knowledge, and strengthening the institutional cooperation in ASEAN become an important point in regional cooperation conducted. Because of that, this institutional strengthening within ASEAN is important to strengthen the coordination 
mechanism and monitoring the implementation of the cooperation mechanism that has been agreed upon in every internal meeting that has been held.

In addition to the priority in the health sector, funding instruments are one of the focuses of cooperation in the EU in preparing a number of assistances to business actors and banking institutions. The type of assistance provided by the EU is to avoid market distortions and revive the affected economic sectors through the provision of loans and adequate liquidity. Several financial support initiatives are used to drive several sectors such as tourism, agriculture, and fisheries.

\section{Conclusion}

COVID-19 not only has an impact on regional cooperation in the health sector but also in other sectors to solve economic recovery. Regional cooperation can be seen in terms of the way of cooperation as well as the mechanism carried out in the implementation of any policies that have been planned. Several initiatives were carried out in responding to COVID-19, starting from cooperation in sharing information, joint research, cooperation in the health sector, to cooperation with partner countries. Regional response to a pandemic is also not confined to one region but also on a broader level as that of the EU in assisting some countries in addressing the COVID-19. The coordination, cooperation and dialogue are also carried out with multilateral institutions in responding to COVID-19.

Partnerships and information transparency are one of the cornerstones of regional cooperation carried out in ASEAN. Also, The policy of member countries in terms of fiscal stimulus is also one of the efforts made to encourage economic recovery. Meanwhile, in the EU, the policy package provided by the EU to member countries is one form of policy in responding to COVID-19, both covering types of policies in the health sector and types of policies related to the economic sector. From the various collaborations that have been carried out, it can be seen that the strengthening of sustainable regional cooperation is important to develop regional strategies in addressing health issues that have an impact on the regional economy.

\section{References}

"Improving ASEAN COVID-19 response: Implementation key". Retrieved from https://www.thejakartapost.com/academia/2020/10/07/improving-asean-covid-19response-implementation-key.html.

----------, 2020c. "Joint Statement Special Video Conference Of Health Ministers of ASEAN and the United States in Enhancing Cooperation on Coronavirus Disease 2019 (Covid-19) Respone". Retrieved from https://asean.org/storage/2020/05/Adopted_ASEAN-US-Joint-Statement-on-COVID19.pdf

--------, 2020d. “Co-Chairs' Press Statement ASEAN-EU Ministerial Video Conference on the Coronavirus Disease 2019". Retrieved from https://asean.org/storage/2020/03/ASEAN-EU-Vid-Con-Press-Statement.pdf

-------. 2020b. "Declaration of the Special ASEAN Summit on Coronavirus Disease 2019 (COVID-19)". Retrieved from https://asean.org/storage/2020/04/FINALDeclaration-of-the-Special-ASEAN-Summit-on-COVID-19.pdf

"Covid-19 : 10 things the EU is doing for Economic Recovery". Retrieved from European Union Parliament Website https://www.europarl.europa.eu/news/en/headlines/eu- 
affairs/20200625STO82007/covid-19-10-things-the-eu-is-doing-for-economicrecovery

ADB. 2020. "An Updated Assessment of the Economic Impact of COVID-19". ADB Briefs No.133.

Amaya, A. B., \& Lombaerde, P. D. (2021). Regional Cooperation is Essential to Combatting Health Emergencies in the Global South. Globalization and Health, XVII(9), 3-4.

ASEAN. (2020a). "Economic Impact of COVID-19 Outbreak on ASEAN". ASEAN Policy Brief April. Retrieved from https://asean.org/storage/2020/04/ASEAN-PolicyBrief-April-2020_FINAL.pdf

Boffey, Daniel. "Coronavirus threatens future of eurozone, Brussels warns". Retrieved from https://www.theguardian.com/business/2020/may/06/coronavirus-threatensfuture-eurozone-brussels-economic-sosial-divisions-pandemic

Echeverria, L. F., Valle, K. A., \& Muller, C. W. (2020). Science Diplomacy and SouthSouth Cooperation for Emergency Response: The Case of COVID-19 Pandemic in Latin America. Jurnal Sosial Politik, 6(2).

European Central Bank. (2020). "ECB announces $€ 750$ billion Pandemic Emergency Purchase Programme (PEPP)". Retrieved from https://www.ecb.europa.eu/press/pr/date/2020/html/ecb.pr200318_1 3949d6f266.en. html

European Commision. "Spring 2020 Economic Forecast: A deep and uneven recession, an uncertain recovery". Retrieved from https://ec.europa.eu/commission/presscorner/detail/en/ip_20_79

European Council. "COVID-19 coronavirus outbreak and the EU's respone". Retrieved from https://www.consilium.europa.eu/en/policies/covid-19-coronavirus-outbreakand-the-eu-s-respone/

European Union. "Coronavirus: European Union launches "Team Europe" package to support partner countries with more than $€ 20$ billion". Retrieved from https://eeas.europa.eu/headquarters/headquarters-homepage/77326/coronaviruseuropean-union-launches-\%E2\%80\%9Cteam-europe\%E2\%80\%9D-packagesupport-partner-countries-more-\%E2\%82\%AC20_en

Eurostat. (2020, November 13). GDP and Employment Flash Estimates For the Third Quarter of 2020. Retrieved from News Relase Euro Indicators: https://ec.europa.eu/eurostat/documents/2995521/10662173/2-13112020-APEN.pdf/0ac3f053-f601-091d-ea21-

db1ecaca7e8c\#: :text=In\%20the\%20third\%20quarter\%20of,office\%20of\%20the $\% 2$ 0European\%20Union

Fernandez, J. E. (2020). A Critical Analysis On The European Union's Measures to Overcome The Economic Impact of The COVID-19 Pandemic. European Papers, $\mathrm{V}(3), 1420-1421$.

Kedutaan Besar RI di Port Moresby. "Mesin Diplomasi ASEAN Terus Bekerja Hadapi COVID-19". Retrieved from https://kemlu.go.id/portmoresby/id/news/6244/mesindiplomasi-asean-terus-bekerja-hadapi-covid-19

Kementerian Luar Negeri RI. "Joint Statement of the Special ASEAN Plus Three Summit on Coronavirus Disease 2019 (COVID-19)". Retrieved from https://kemlu.go.id/portal/i/read/1206/pidato/joint-statement-of-the-special-aseanplus-three-summit-on-coronavirus-disease-2019-covid-19

Kimura, et,al. (2020). Pandemic (COVID-19) Policy, Regional Cooperation and the Emerging Global Production Network. Asian Economic Journal, XXXIV(1), 16-17. 
Knapp, N.M. (2011). "Regional and interregional integrative dynamics of ASEAN and EU in respone to the avian influenza". Asia Europe Journal 8 (4): 541-554. DOI $10.1007 / \mathrm{s} 10308-011-0289-8$

Loasana, N. (2020). "EU donates $€ 350$ million to help ASEAN countries battle COVID19". Retrieved from https://www.thejakartapost.com/news/2020/04/28/eu-donates350-million-to-help-asean-countries-battle-covid-19.html

Menon, J. (2020). "Assessing the Economic Impacts of COVID-19 on ASEAN Countries". Retrieved from https://www.eastasiaforum.org/2020/03/27/assessing-the-economicimpacts-of-covid-19-on-asean-countries/

Murphy, M., Jeyasselan, S., Howitt, C., Greaves, N., Harewood, H., Quimby, K., . . . Hambelton, I. (2020). COVID-19 Containment in The Caribbean: The Experience of Small Island Developing States. Journal Research in Globalization2020, 2(100019).

Papageorgiou, M, dan Melo, D.S.N. (2020). "Regional responses to COVID-19: A comparative analysis of EU and ASEAN policies to counter the pandemic". Perspectives on Federalism, Vol. 12, issue 1

Poluakan, M. V., Dikayuana, D., Wibowo, H., \& Raharjo, S. T. (2019). Potret Generasi Milenial pada Era Revolusi Industri 4.0. Focus: Jurnal Pekerjaan Sosial, 2(2), 187197.

Rubenstein, L.S. 2010. "Cooperation and Tension in Regional and Global Infectious Disease Surveillance". Peacebrief 34, June 1. Retrieved from https://www.usip.org/sites/default/files/resources/pb34.pdf

Sisilawati et al. (2020). Impact of COVID-19's Pandemic on the Economy of Indonesia. Budapest International Research and Critics Institute-Journal (BIRCI-Journal). P. 1147-1156.

Thomas, N. (2006). The Regionalization of Avian Influenza in East Asia: Responding to the Next Pandemic(?). Asian Survey, XLVI(6), 928-929.

Widian, R., \& Omega W, V. (2020). ASEAN Regional Potentials For Combating COVID19. Jurnal Ilmu Hubungan Internasional: Edisi Khusus, 16(1).

World Economic Forum. (2020). "What the world can learn from regional respones to COVID-19". Retrieved from https://www.weforum.org/agenda/2020/05/covid-19what-the-world-can-learn-from-regional-respones/

Zhengyue. H. \& Xinyu, Z. (2020). "New era of regional cooperation". Retrieved from https://www.thejakartapost.com/academia/2020/05/15/new-era-of-regionalcooperation.html 